\title{
THE SUBSPECIES OF SPHAERODERUS CANADENSIS CHD.
}

\author{
By P. J. DARLington, JR. \\ Museum of Comparative Zoölogy, Cambridge, Mass.
}

Chaudoir described Sphaeroderus canadensis (Bull. Soc. Imp. Nat. Moscou 34, (1), 1861, pp. 498-9) in considerable detail, giving the type locality as Canada, probably near the Ottawa River. S. palpalis Mots. (ibid. 38, (4), 1865, p. 312) from "Hudson Bay" is placed as a synonym of canadensis by Roeschke (Ann. Nat. Mus. Hungary 5, 1907, p. 263), probably correctly, although Motschulsky's description of the elytra as "profunde crenato-st $[r]$ iatis" does not fit typical canadensis very well. Sphæroderus blanchardi Leng (Journ. New York Ent. Soc. 24, 1916, pp. 41-2), described as a subspecies of canadensis, is a pure synonym of the latter. Not only do paratypes of blanchardi in the Blanchard Collection in the Museum of Comparative Zoölogy answer the description of canadensis perfectly, but they are very closely matched by a specimen from Canada in the Leconte collection. This Canadian specimen lacks the setigerous punctures of the 4th and 8th elytral intervals just as New England (blanchardi) specimens usually do, and is not otherwise separable, although the elytral striæ are a little more distinctly punctured than in most New England specimens. The difference, however, is too trifling to be significant.

Although Leng was mistaken in describing a New England race, Sphæroderus canadensis does divide into two geographical subspecies on much the same characters which Leng (loc. cit.) points out. However, it was the southern, not the northern form which was undescribed, and which may now be separated under the following name: 
Sphæroderus canadensis lengi, subsp. nov.

Closely similar to typical canadensis in size, form, and color. Differs chiefly in having the elytral striæ more heavily punctate, the intervals more interrupted posteriorly, and the sculpture heavier and more irregular throughout; in having the 11th interval more elevated apically, forming a distinct cariniform tubercle at the declivity, especially in the $o$; and in having the 4th and 8th elytral intervals each with several (usually 5 or 6 or more) setigerous punctures. In the last character it differs from northern specimens of true canadensis but not from some specimens I have seen from the Black Mts., especially Mt. Mitchell, N. C. Length 10-11.5 mm.

Holotype $\hat{o}$, allotype $q$, and 4 ( $\hat{o} \hat{\delta}$ ) paratypes from between Newfound Gap and Clingman's Dome, 5,000-6,600 ft., on the North Carolina-Tennessee state line. One o paratype from Newfound Gap itself. One $q$ paratype from State Road to Newfound Gap, Tennessee side, 3,500 ft. All the preceding localities are in the Smoky Mts.; the specimens were collected by the writer August 31Sept. 3, 1930. Also 6 paratypes $(5 \hat{o} \hat{\delta}$, o $)$ from Highlands, North Carolina, Blanchard Collection. All of the type series, except 3 paratypes in the writer's collection, are in the Museum of Comparative Zoölogy, type number 17,238 .

S. canadensis differs from all other Sphæroderus in having the elytra only 12-striate. Of the characters given above to separate the two subspecies only the setigerous punctuation of the 4th and 8th elytral striæ needs special discussion. In typical canadensis from the North these intervals are usually impunctate, but there is one setigerous puncture on the 4th interval of the left elytron of each of two of of from Mt. Madison, N. H. There is one on the 4th interval of a $q$ from Isle-au-Haut, Me. A $\hat{\sigma}$ from St. Vincent, Penn., has 4 on the left, 3 on the right 4 th interval, none on the 8th interval. A $\&$ from Virginia has two on each 4th interval. A $\hat{\sigma}$ and $\&$ from Boone, northern North Carolina, have the 4th and 8th intervals impunctate, as has a $q$ from near Linville, northern 
North Carolina, but another $q$ and a $\hat{\alpha}$ from the latter locality have a single puncture apiece on one 4 th interval. A ô from "Black Mts., N. C., VI. 1-15, 1912" has a total of 3 punctures on the 4th and 8th intervals; another $\hat{o}$ with identical label has a total of 15 . Specimens from near the top of Mt. Mitchell, N. C., usually have rather numerous punctures on the intervals in question, but seem to be otherwise hardly distinguishable from northern specimens, and the bristle character alone is so inconstant that I do not think a local race should be based on it. I therefore consider that there are only two reasonably distinct subspecies of Sphæroderus canadensis: (1) S. canadensis canadensis Chd. (palpalis Mots., blanchardi Leng) which ranges from eastern Canada to the Black Mts. of northern North Carolina, and (2) S. canadensis lengi Darl., occurring in the mountains of southwestern North Carolina and adjacent parts of Tennessee and probably also in parts of Georgia and Alabama. 

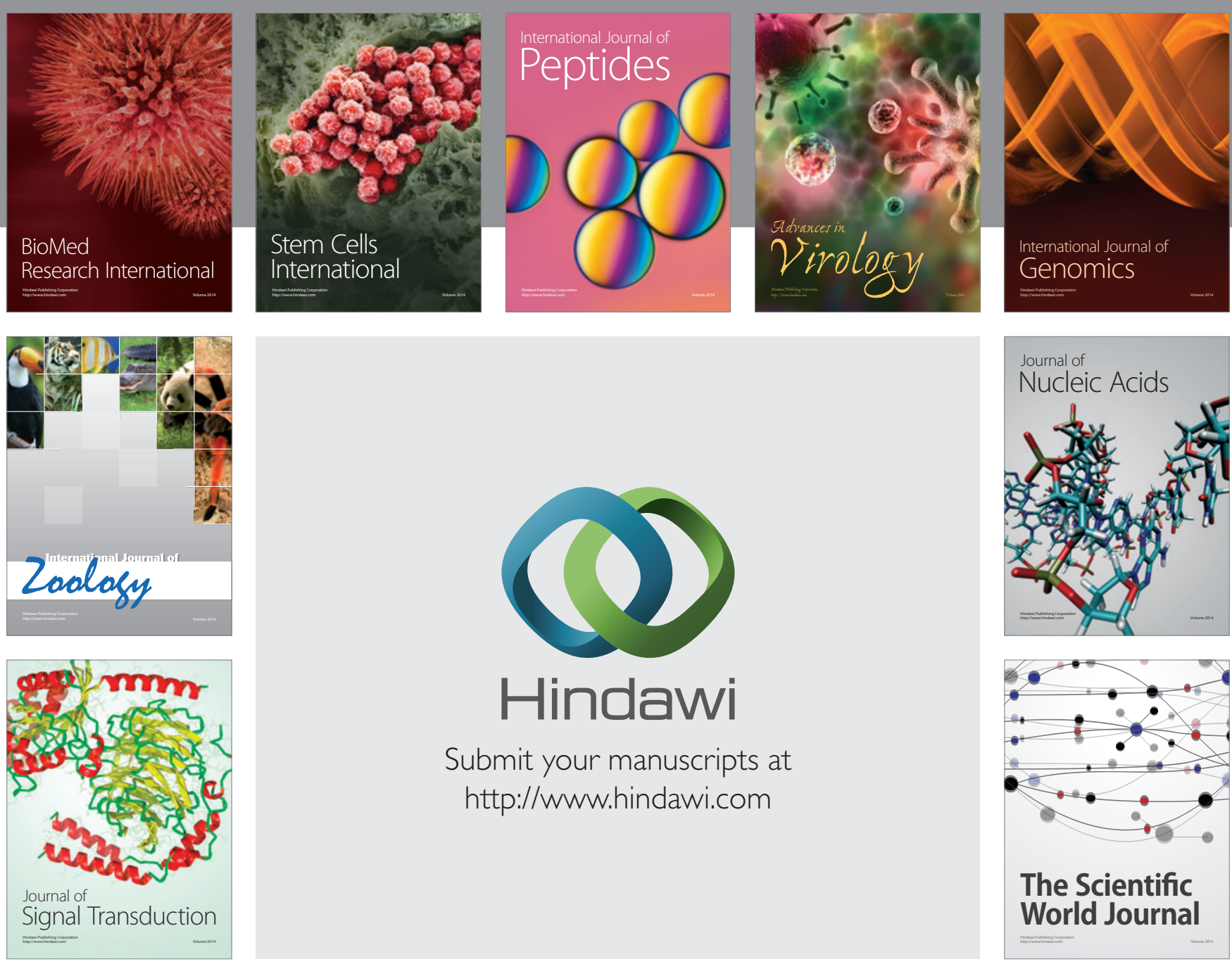

Submit your manuscripts at

http://www.hindawi.com
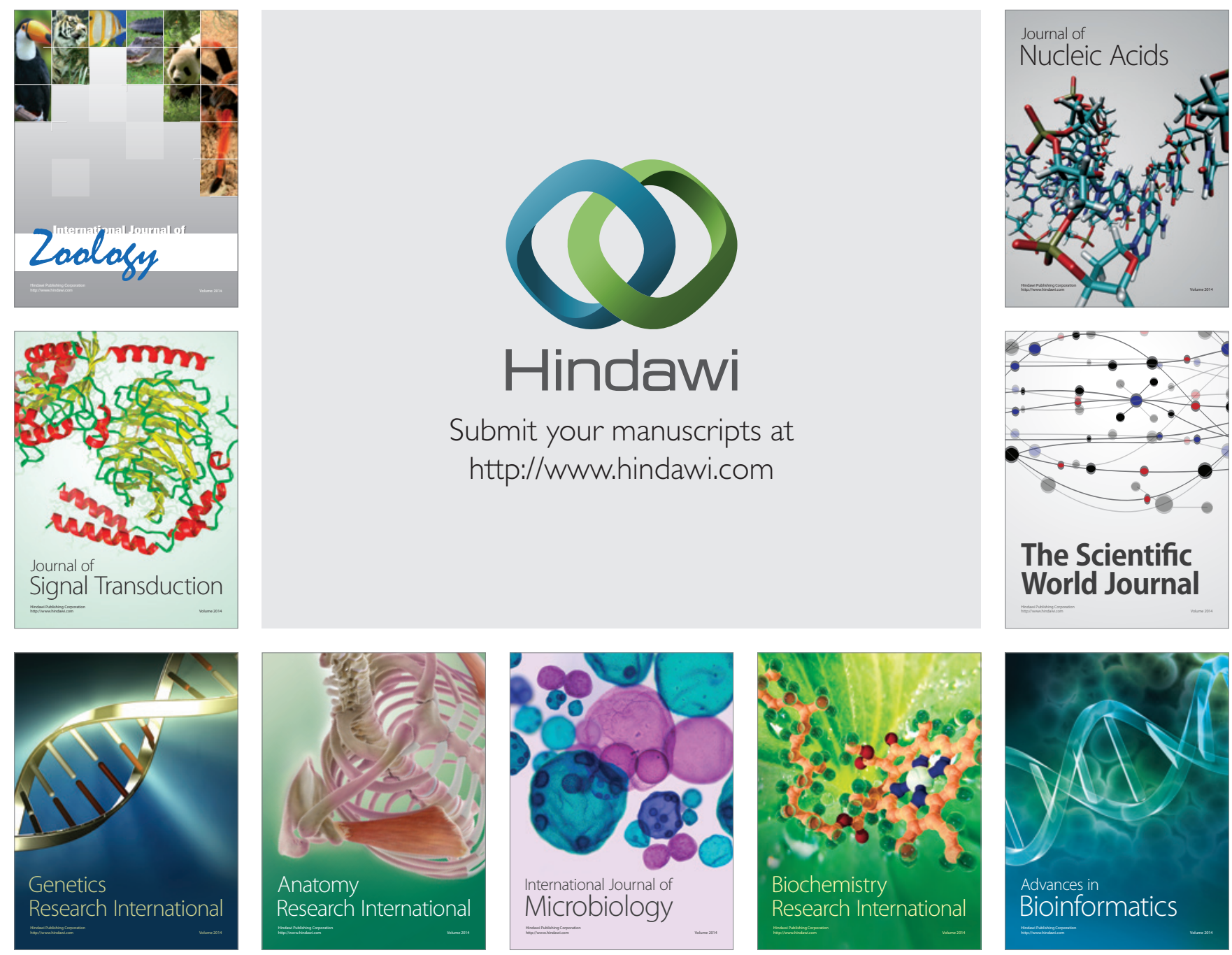

The Scientific World Journal
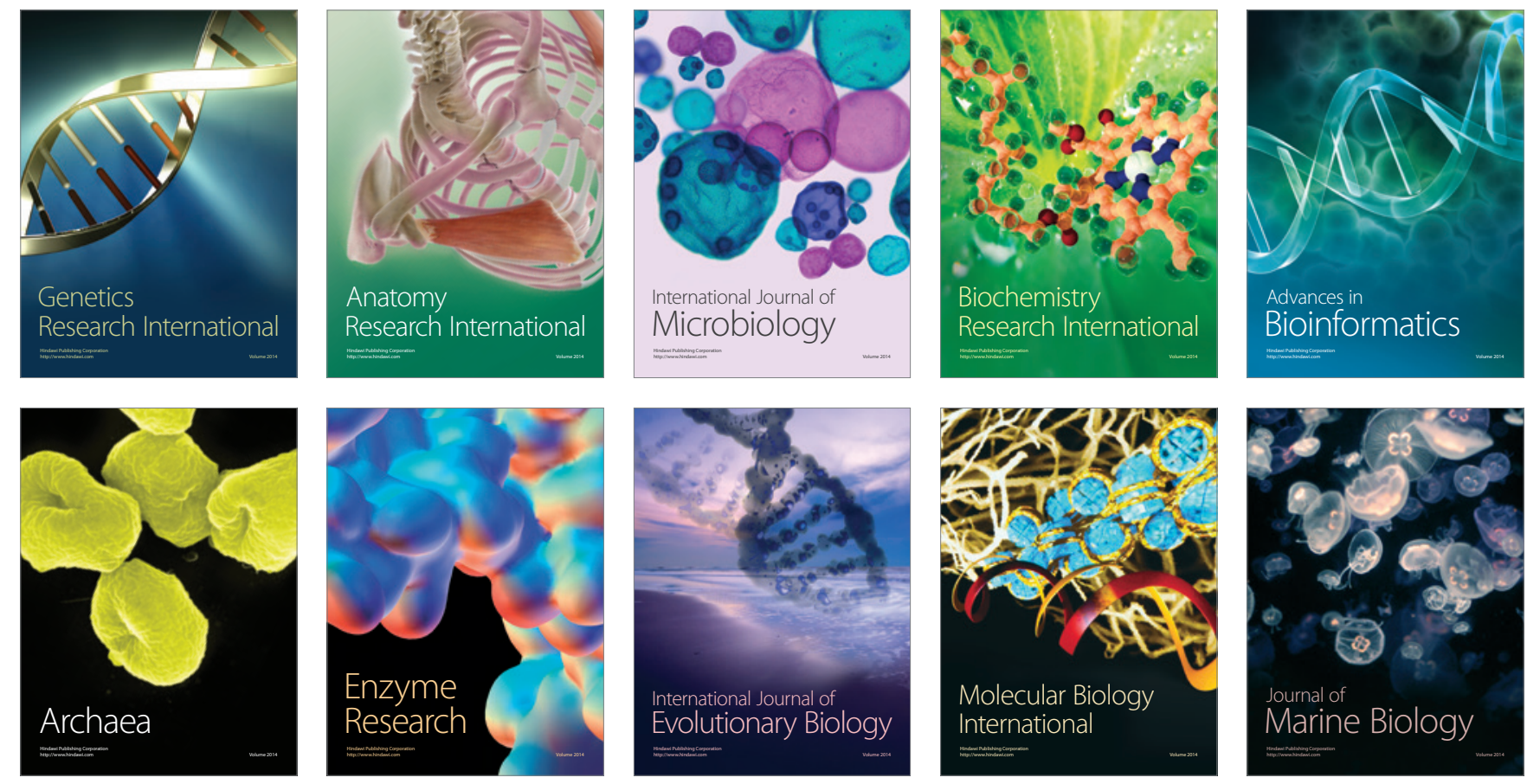